\title{
CHINESE PERSPECTIVISM: PERSPECTIVIST COSMOLOGIES IN ZHUANGZI AND JOURNEY TO THE WEST
}

\author{
Erki Lind
}

\begin{abstract}
Perspectivism as a cosmology, according to which all beings perceive themselves as humans, has been discussed mainly in connection with the Amazonian region, for the term perspectivism stems from Eduardo Viveiros de Castro, who applied it to the indigenous worldview of that particular region. To a lesser extent, it has also been studied in North Asia and some other hunter-gatherer societies. In this article I wish to demonstrate that perspectivism may be more widespread than previously thought, and its occurrence is not necessarily limited to hunter-gatherer cultures. Perspectivism can also be found in pre-modern China, which can be seen from such well-known texts as Zhuangzi (4th-3rd century $\mathrm{BCE}$ ) and Journey to the West (16th century).

The connecting link that makes the occurrence of perspectivism possible both in South America and East Asia is probably shamanism, which is present in both of these regions. It is characteristic of Chinese perspectivism that the multiple perspectives are not equal, but there is one proper perspective that is at the same time also the moral perspective. Chinese cosmology can contribute to the understanding of American perspectivism with its concept of cosmological relations, which fits the model of perspectivism.
\end{abstract}

Keywords: Amazonian perspectivism, Chinese literature, Chinese philosophy, cosmology, Daoism, Journey to the West, perspectivism, Zhuangzi

\section{INTRODUCTION}

Since the 1990s, the notions of animism and totemism ${ }^{1}$ have regained importance in anthropological discourse (see Halbmeyer 2012; Willerslev \& Ulturgasheva 2012; Costa \& Fausto 2010: 16-17), and a new theory, perspectivism, has been introduced. Perspectivism originally dealt only with South America, but has now been extended to include some other cultural areas as well. In this article, I wish to examine whether perspectivism can also be applied to classical China.

When speaking about perspectivism, I do not refer to the philosophical term, but to the theory by Eduardo Viveiros de Castro, which describes the 
peculiarities of Amazonian cosmology and anthropology. It states that all beings see themselves as humans or persons, or other species according to their importance in relation to the species in question. So perspectivism can prove itself important in understanding and explaining the relations between humans, animals and spirits, and also regarding the conceptions about the human body. In addition to Viveiros de Castro (1998), other researchers have written about perspectivism; for example, Broz (2007), Silva Guimarães (2011), Lima (1999), Londoño Sulkin (2005), Kristensen (2007), Pedersen (2001), Rasmussen (2011), Rival (2005), Turner (2009) and Vilaça (2005).

My aim is to bring closer together anthropology and religious studies or history of religions as a historical discipline that operates with texts. Of these two, anthropology has laid more emphasis on theoretical approach, and I believe that some of the theories can also be helpful for studying organised religions and written texts. Viveiros de Castro (2010) has said that anthropology compares anthropologies, and this is why I dare to compare two very different anthropologies - those of the Amazonian region and classical China.

In this article, I will first examine Chinese texts from a perspectivist point of view and then discuss what perspectivism can offer to Chinese studies and vice versa. The Chinese texts I used for comparison with perspectivism are Zhuangzi and Journey to the West. These two texts stem from different epochs, have a completely different cultural background and are composed with different objectives. Zhuangzi is a philosophical and religious text from the 4th-3rd century BCE and one of the founding texts of Daoism, whereas Journey to the West is a folk novel from the 16 th century $\mathrm{CE}^{2}$. It was a deliberate choice to use texts that were composed in different eras and belong to different genres. By doing this, I wish to encompass the widest spectrum possible with as few texts as possible, because I do not wish to show the perspectivist nature of one particular tradition, but to demonstrate the possibility of perspectivism in other cultural areas and to prove that it may be a much more widespread phenomenon than previously thought. These two texts have their influence and famousness in common, which makes them both relevant and exemplary.

\section{AMERINDIAN PERSPECTIVISM}

Eduardo Viveiros de Castro introduced the notion of Amerindian perspectivism in 1998, with the article "Cosmological Deixis and Amerindian Perspectivism". The role of the 'point of view' in Amazonian cosmologies was also examined by Tânia Stolze Lima (1999). 
Perspectivism deals with "ideas in Amazonian cosmologies concerning the way in which humans, animals and spirits see both themselves and one another" (Viveiros de Castro 1998: 469). In normal conditions, humans perceive humans as humans, animals as animals and spirits (if they see them) as spirits (ibid.: 470). What makes it special is the fact that animals and spirits also see themselves as humans:

They perceive themselves as (or become) anthropomorphic beings when they are in their own houses or villages and they experience their own habits and characteristics in the form of culture - they see their food as human food, they see their bodily attributes as body decorations or cultural instruments, they see their social system as organized in the same way as human institutions are. (ibid.)

Thus they see things as 'people' do, but the things that they see are different (ibid.: 478). For example, blood is beer for jaguars (Vilaça 2005: 457) and the tapirs see a muddy waterhole as a great ceremonial house (Viveiros de Castro 1998: 478).

A different approach in its definition is used by Lima, yet she describes the same phenomena: "Point of view implies a particular conception according to which the world only exists for someone" (Lima 1999: 117). This is also reflected in the grammar of some languages. The Jurúna say, for example: "This is beautiful to me", and "To me, it rained" (ibid.).

Perspectivist cosmology is essentially connected with the concepts of body, for the body is the origin of perspectives (Viveiros de Castro 1998: 478). The body itself is seen, on the one hand, as an envelope or clothing (ibid.: 471), on the other hand, as an assemblage of affects or ways of being that constitute a habitus (ibid.: 478). It is largely accepted in anthropology that the body is a concept that is culturally constructed (Asad 1997) and in South American indigenous cultures it is literally the case. Vilaça writes about the Wari' that their bodies are continually fabricated and also comprised of affects and memories (Vilaça 2005: 449). The 'soul', Vilaça explains, enables one "to change affection and to adopt other habits, thus enabling the person to be perceived similar to other types of beings" (ibid.: 452). Thus the body and the perspectives that are derived from it are processes, and as processes they can undergo transformations. I believe that the potential transformation plays a crucial role in the understanding of perspectivism. For shamans, transformation is an essential means for performing their tasks. For everyone else, however, it poses a danger of losing one's human perspective. 
The importance of the body also builds a basis for Terence Turner's argumentation in his critique of Viveiros de Castro's article (Turner 2009). According to him, Viveiros de Castro dismisses the outward forms as mere "envelopes" (ibid.: 19), and both the body and the perspective are conceived as "singular, unchanging entities" (ibid.: 38). So he proposes that the "notion of the body as the origin of perspectives [---] should be substituted by a conception of both bodies and perspectives understood as sequences of multiple transformations. [---] conceiving the body in appropriate structuralist terms as such a series of transformations opens a perspective on bodiliness as a process of interaction of the physical body, social body, and person, stimulated and guided by relations with other embodied actors filtered and regulated by formal treatments of their bodily surfaces ("social skins")" (ibid.: 38). However, this is also how I understand Viveiros de Castro's perspectivism. The body is seen as habitus, thus produced as a process, and subject to potential transformation.

In addition, Turner writes that humans do not share culture with animals and that the creation myths tell us how humans attained culture and how the differentiation of the species, and with that their respective subjective identities and perspectives, came about as a "corollary result of the one-sided possession of culture by humans" (ibid.: 19). This does not necessarily invalidate the theory of perspectivism, but rather adds an extra dimension to it. With examples from China it will be shown how perspectivism can also describe this process of differentiation. By acquiring a human perspective, the animals may try to reconquer culture. This is what makes the change of perspective and transformation dangerous to humans.

It must be noted that the precondition for these considerations is that the human perspective and culture are the same. However, it would be reasonable to drop the nature-culture opposition, because perspectivist cosmology and anthropology do not need the opposition and, moreover, it would be rather difficult to integrate this opposition in the schemata of perspectivism.

As the Amazonian region is not homogenous but has a multitude of different cultures, so does perspectivism have several forms. It becomes most apparent in an article by Carlos Londoño Sulkin about perspectivism among the Muinane people (Londoño Sulkin 2005: 24). It diverges from the schemata of Viveiros de Castro in two aspects: firstly, humans and animals are not equal and, secondly, being human is being moral.

Perspectivism has been one of the most discussed topics in South American studies and thus different views have been expressed about it. The most prominent alternative has been P. Descola's animism. The two scholars, Descola and Viveiros de Castro, have even held public debates about the topic (Latour 2009). More recently, many anthropologists have held the view that neither of the two 
models are fully applicable and argued that choosing only one ontological model is too much of a simplification and does not describe the worldviews of different indigenous Amazonian cultures adequately (Willerslev \& Ulturgasheva 2012: 50; Halbmeyer 2012: 14).

What are the outcomes if we look for perspectivism in other cultures? Two questions must be answered for that: Is perspectivism limited to the Amazonian region? What are the socio-cultural preconditions of perspectivism? To the first question Viveiros de Castro answered that "it can also be found, and maybe with even greater generative value, in the far north of North America and Asia, as well as amongst hunter-gatherer populations of other parts of the world“ (Viveiros de Castro 1998: 471).

Since then several articles have been published that deal with Northern and Inner Asian perspectivism (Pedersen 2001; Broz 2007; Kristensen 2007). Before moving on to China, which is the aim of this article, I would like to point out that analogous notions can also be found in other cultures and religions; for example, in Mahāyāna Buddhism (Mrozik 2007). Mrozik describes a situation where one's identity depends on another's perspective in monastic life:

It is important to note that bodies change not only over time, but also according to circumstance. For instance, junior monks must engage in physical displays of respect such as bowing when in the presence of senior monks. A monk might be junior in one relationship and senior in another. His body language will change accordingly. (Mrozik 2007: 32)

Two further things can be pointed out here: the instability of the body, which has been described as a feature of perspectivism by Vilaça (2005), and relationships of dominance or seniority, which is a feature of Duha perspectivism (Kristensen 2007).

Further on, there is a very interesting passage in the Vimalakīrtinirdeśa Sūtra (2006: 1.16). A man called Śāriputra says to Gautama Buddha that his Buddhafield must be impure, because the world we live in is impure. To that a Brahmā answers that it is Sāriputra's mind that is impure, because he sees the world as magnificent as the celestial dwellings of gods.

Now, as we have seen that the occurrence of perspectivism is not geographically limited, let us turn to the socio-cultural presuppositions and compare these to the situation of Classical China. Relations between predator and prey are intrinsic to Amazonian perspectivism (Viveiros de Castro 1998: 471); this would require a hunter-gatherer society. This is a major difference and could be a decisive factor, if it were not proven by Pedersen (2001) that perspectivism occurs also in pastoral Mongolia. For him, the presuppositions of perspectivism are the classical anthropological notions - 'animism' and 'totemism'. However, 
he does not define totemism narrowly as kinship with animals, but as a categorised cosmology. Yet, the latter is especially well-developed in China.

Next to the relations between predator and prey, Viveiros de Castro (1998: 472) mentions that "Amerindian perspectivism has an essential relation with shamanism". Shamanism, which is the essential basis of perspectivism, is the connecting link between the Americas and East Asia and especially China, for shamanism has been historically present there (Robinet 1997: 37; Schipper 1993: 6) and can be still found, especially in Korea (Kim 2003), but also in Chinese folk religion (DeBernardi 1995).

\section{PERSPECTIVISM IN CHINA: ZHUANGZI}

Zhuangzi is, besides the Daodejing, one of the founding texts of Daoism. This book and the philosopher with the same name from the ca 4 th century BCE make use of many literary devices, and perspectivism is one of them. However, it is perspectivism mainly in its wider or philosophical sense: "Zhuangzi uses perspectivism, the claim that all knowledge is relative to the observer's point of view, to undercut our normal standards for making value judgements" (Ivanhoe 1993: 645). Perspectivism is also used in Zhuangzi for epistemological arguments. Zhuangzi distinguishes between two kinds of knowledge: greater knowledge (da zhi 大知) and lesser knowledge (xiao zhi 小知) (Connolly 2011: 495), and D. Sturgeon (forthcoming) argues that "greater knowledge is the kind of knowledge that holds from a greater range of perspectives". In the text, perspectives change constantly, and as T. Connelly says, the "person who can shift perspectives simply knows more about things than the one who does not" (Connolly 2011: 502).

As the change of perspective is one of the central themes in Zhuangzi, he uses it mainly to transmit philosophical and moral ideas.

Already the first chapter of the book tells us a parable of the giant bird Peng and a small dove, which shows how the value of things depends on the point of view. Another good example of such philosophical perspectivism is chapter 2.8., where Zhuangzi demonstrates the subjectivity of knowledge through examples, which show how notions like 'beauty' or 'convenience' mean different things to different species. This chapter takes us already closer to Amazonian perspectivism, because this is a case of "one culture, different natures", as Viveiros de Castro (1998: 478) called it, because different species share the same categories, but not the things that belong to them. This is, however, no perspectivism in a cosmological or anthropological sense, but an epistemological argumentation. 
So the question remains whether cosmological perspectivism as that in Amazonian region is to be found in Zhuangzi. I found six episodes altogether that can be interpreted as such. These are some of the most important and famous episodes of Zhuangzi, which do not, by any means, much consider the volume of the text.

First of all, I regard the probably most famous chapter in Zhuangzi, entitled "The Butterfly Dream" (2.12), as perspectivist. The story reads as follows:

Once Zhuangzi dreamt he was a butterfly, a butterfly flitting and fluttering around, happy with himself and doing as he pleased. He didn't know he was Zhuangzi. Suddenly he woke up and there he was, solid and unmistakable Zhuangzi. But he didn't know if he was Zhuangzi who had dreamt he was a butterfly, or a butterfly dreaming he was Zhuangzi. Between Zhuangzi and a butterfly there must be some distinction! This is called the Transformation of Things. (Watson 1968: 49)

This famous tale has had many interpretations through centuries, but the last sentence, "This is called the Transformation of Things", gives a hint about which interpretation might be correct. In this tale, both the transformation and the change of perspective are present. This could mean that Zhuangzi may have wanted to say that transformation, which has a central role to play in Chinese cosmology, is nothing else than a change of perspective, or that a change of perspective can help one to understand transformations. Both possibilities can be reduced to the Daoist idea of the unity of cosmos, which states that all phenomena are the transformations of One and in constant change and movement: "Hua [transform] is the natural Tao and the movement of yin and yang" (Robinet 1997: 154). This makes it clear that when discussing transformation, Zhuangzi talks about cosmology.

The aforementioned "different natures" by Viveiros de Castro is by no means contradictory to the Daoist notion of the oneness of nature. Moreover, "The Butterfly Dream" explains why it is like that. The many worlds that depend on the perspective of the beholder come into being from the One through transformations. One world or the One, Dao or $q i$, is constantly transforming, bringing forth countless different worlds.

What is missing here is the perspective of the other, which is, according to Viveiros de Castro, important for the transformation (Viveiros de Castro 1998: 483). Only two 'I'-perspectives are being compared in this tale, but the other, for whom Zhuangzi would be either himself or the butterfly, is absent. This could mean that Zhuangzi himself was also the other perspective. This would correspond to the role of the shaman in the Amazonian region, for a shaman is able to transform and thereby preserve his own perspective. It is also impor- 
tant to note that the transformation occurred in a dream, because "particular elements that are preserved in some dreams in Chinese folklore are similar in structure and form to shamanic experiences as elaborated by Mircea Eliade, and that this similarity allows for an analysis of these elements as genuine representations of a type of shamanic experience" (Giskin 2004). Dreams are equally important for the change of perspective in Amazonia. Lima (1999: 114) writes that dreams are the primary plane of communication between 'real' humans and various animal species (and other ontological categories such as ogres and spirits).

In this story, perspectivism is the cosmological presupposition, possibly derived from the shamanic tradition of South China, for transmitting a Daoist message. In another famous chapter, perspectivism is also the message of the story. In chapter 17.13., Zhuangzi and his friend, philosopher Huizi, are walking by the water, and Zhuangzi tells his companion that the fish are enjoying themselves. To the question how he knows that, he answers that he knows it by how he himself enjoys walking by the water. Playing in the water is thus the same as walking by the water for Zhuangzi, a human.

Let us take a look at some other chapters as well. A very interesting idea is expressed in chapter 22.11.:

The ancients, amid (all) external changes, did not change internally; now-a-days men change internally, but take no note of external changes. When one only notes the changes of things, himself continuing one and the same, he does not change. (Legge 1891)

The changes, hua, as in "The Butterfly Dream", could also be translated as transformations. Here, the shamanic properties of keeping their own (internal) perspective while changing or transforming their appearances are attributed to the ancients, whilst nowadays men act according to Vilaça's notion of 'chronically unstable bodies', i.e., they can be transformed by an outside power without themselves even noticing.

A similar case of transforming the outer form and keeping the perspective is presented in chapter 13.8., where Laozi is the one transforming. However, the Chinese text leaves room for different interpretations. For example, in translation by Legge (1891), Laozi says: "Yesterday if you had called me an ox, you might have done so; or if you had called me a horse, you might have done so", whereas Wilhelm's German translation is much more interesting: "Hättet Ihr mich einen Ochsen genannt, so wäre ich eben ein Ochse gewesen; hättet Ihr mich ein Pferd genannt, so wäre ich eben ein Pferd gewesen" (Wilhelm 1981 [1912]: 151) ('Had you called me an ox, I would have been one; had you 
called me a horse, so I would have been one). A parallel to that can be found in Zhuangzi 7.1., where the sage sleeps in tranquillity and awakes in simplicity, then appearing as an ox and as a horse, because of his knowledge of the nature of everything.

These are clearly Daoist passages and are conveying Zhuangzi's Daoist ideas. Yet the change of perspective is mostly interpreted as being of purely philosophical nature. I would, however, like to emphasise that the philosophy of an ancient philosopher, who lived in the 4th century BCE, cannot be viewed separately from cosmology. Due to Viveiros de Castro's perspectivism it is easier to understand. Essentially, perspectivism in Zhuangzi is a cosmological notion similar to that of the Amazonian peoples, and part of the Daoist idea of reducing the whole of cosmos to one common principle, and of its constant transformation. To master that, true knowledge is required, which is also the Daoist goal in Zhuangzi.

\section{PERSPECTIVISM IN CHINA: JOURNEY TO THE WEST}

Wu Cheng'en's Journey to the West represents the plurality of religious ideas in Ming China in the 16th century. In this book Daoist, Buddhist and folkloristic material is found and made fun of. The focus lies on Buddhism, because the main story is bringing Buddhist scriptures from India to China, and thus the concepts of humans and spirits are also Buddhist. The Buddhism in the Journey to the West is, however, Chinese folk Buddhism mainly associated with magic powers.

This book offers many things that are of interest for this article. For one thing, transformations and metamorphoses constitute an intrinsic part of its plot. The main character, Monkey King Sun Wukong, who accompanied monk Tripitaka on his journey, is said to possess 72 transformations as part of his magical powers, which he had acquired from a Daoist immortal called Bodhi. The other companions were transformed from celestial beings to evil spirits and back again.

Yet, most remarkably perspectivist in the Journey to the West is the transformation of animals into dangerous spirits, thus in the following chapter I will concentrate on this theme.

In chapter 22 in Waley's translation and chapter 20 in Yu's, begins an episode where Tripitaka and his companions reach the Country of Cart Slow. In this land Buddhism is oppressed and Daoism flourishes because three alleged Daoist immortals, Tiger Strength Immortal, Deer Strength Immortal and Ram Strength Immortal, have won the king's favour. Sun Wukong then competes 
with them in various dangerous tasks, in which all the three find their end and are revealed as animals - as actual tiger, deer, and ram.

It all started as these animals managed to appear as Daoist immortals to the king. But why did he see them as humans? By way of comparison, I would like to bring a fairly similar story of the Wari' people in Brazilian Amazonia, written down by Aparecida Vilaça:

While the human form is a strong indication of a human being, it may nonetheless be deceptive. It is always best to distrust one's own eyes. An event which befell some of my Wari' friends provides a perfect example. A child is invited by her mother to take a trip to the forest. Many days go by as they walk around and pick fruit. The child is treated normally by her mother until one day, realizing just how long they have spent away from home, the child starts to grow suspicious. Looking carefully, she sees a tail discreetly hidden between her mother's legs. Struck by fear, she cries for help, summoning her true kin and causing the jaguar to flee, leaving a trail of paw-prints in its wake. One woman, telling me about this event, said that, after finding her, the girl's true mother warned her to always distrust other people. Whenever she went far from home, either with her mother or father, she should take along a brother or sister as company (in order, I assume, to secure her point of view). (Vilaça 2005: 451)

Both the king and the Wari' child were turned into the objects of the other, in both cases this subject was an animal. Viveiros de Castro writes that "he who responds to a 'you' spoken by a non-human accepts the condition of being its second person. [---] The canonical form of these supernatural encounters, then, consists in suddenly finding out that the other is 'human', that is, that it is the human" (Viveiros de Castro 1998: 483). Lima (1999: 124) makes it even clearer: "The animal should not be given a chance to speak".

The second question related to the first is why the king saw them after their death as animals that they really were. The situation is described as follows:

'How can you be so deluded?' said Monkey, coming up to him. 'Have you not seen that the first Immortal's corpse showed him to have been merely a tiger? The second has turned out to be a common deer. And if you have the bones of the third fished out of the cauldron, you will find that he was nothing but a ram, the bones of which could never be mistaken for those of any human being.' (Waley 1958 [1942]: 247)

Most importantly, it shows that the transformation was not bodily or physical because the animals only appeared human to the king. This means that it is 
precisely the body that differentiates between the species, as Viveiros de Castro claimed about the Amazonian perspectivism (Viveiros de Castro 1998: 478). To illustrate this, he used the anecdote from Lévi-Strauss's famous speech. A short time after the discovery of America, the Spanish on the Greater Antilles were trying to find out whether the natives had a soul or not, whereas the natives were at the same time busy drowning the white people they had captured in order to find out whether or not the corpses were subject to putrefaction (LéviStrauss 2010; Viveiros de Castro 1998: 475). The reason, according to Viveiros de Castro, was that, unlike Europeans, they believed that animals and spirits had souls as humans did, and their objective was to find out whether Europeans had the bodies of humans or the bodies of spirits.

But let us return to the Journey to the West. After leaving the Country of Cart Slow, the travelling party met another monster. In chapter 25 in Waley's translation, Tripitaka and his companions reached a river that led to the heaven. There was a temple of the Great King of Miracles, a wrathful deity, who, as a price for sending rain and fertility, demanded a boy and a girl as yearly sacrifices and devoured them. Sun Wukong and Zhu Bajie defeated the monster, who then retreated into the river. However, when the party tried to cross the river, Tripitaka fell into the water and got captured by the Great King in his underwater palace.

After he was defeated, yet again it appeared that the monster was just an animal, namely a goldfish. So this episode can also be compared to the Amazonian notions. In Amazonian perspectivism it is believed that animals see the places they live in as villages. Here we have fish that lived in a palace. The question is, whether there actually was a palace underwater, or the goldfish and his followers perceived it as a palace. In the text there is one strong hint that the underwater kingdom was a matter of perspective, namely what the Bodhisattva Kuanyin said about the monster:

It is a goldfish that I reared in my lotus pond. Every day it used to put its head out and listen to the scriptures, thus acquiring great magical powers. Its mallet was a lotus stalk, topped by an unopened bud. (Waley 1958 [1942]: 275)

Thus the goldfish became Great King of Miracles by listening to Buddhist scriptures. Such progress is typical of the Chinese thought and will be examined more closely later on. However, the goldfish also had a special weapon, just like Sun Wukong, but he had not received it from a supernatural being as Sun Wukong had, but it was a lotus stalk turned into a mallet. The lotus stalk could not have transformed due to the hearing of scriptures, so the only possible 
explanation is a perspectivist reading. A lotus stalk was a miraculous mallet for a goldfish-turned-into-monster.

The goldfish acquired either the human perspective or that of a powerful spirit by listening to the scriptures, i.e., he had earlier considered himself a goldfish and then a human or a spirit, or, through the power of the scriptures, he had gained the power to enforce his own perspective on others, including humans. The first possibility differs from the Amazonian perspectivism, where all the beings see themselves as humans. The second one, however, would be comparable to the Amazonian notion.

\section{DISCUSSION}

Finally I would like to discuss what perspectivism could offer to Chinese studies and, also, what Chinese sources could contribute to the theory of perspectivism. I would thus like to present some further ideas for theoretical discussions. Such a theoretical sketch may be too abstract, yet abstractions and generalisations cannot be avoided here.

A broader question that the topic poses is about the conception of the human being: who is human, what makes humans human, as well as the relations between humans and animals, spirits and gods. Amazonian perspectivism presupposes a similar soul for all living beings (and perhaps also things) (Santos-Granero 2009). Thus the difference lies in the body, which is also the source of the perspective. Yet, the body is very unstable and cannot be relied upon. The perspective can be changed and the body is transformable.

Here, the use of the notion of the soul is problematic, because different cultures have different worldviews and the concept of the soul is clearly rooted in the Western thought. For example, for the Wari' people, the soul is jam, which implies the capacity to jamu, transform. Jamu "indicates a capacity to change affection and to adopt other habits" (Vilaça 2005: 452). This idea differs clearly from the Western notion and also helps to understand the background of perspectivism.

In the Chinese thought, the difference between humans, spirits and gods is not qualitative but quantitative. Intrinsic to Chinese cosmology are smooth transitions, diffuse boundaries and a continuity of being, meaning that all things form a continuum ( $\mathrm{Tu}$ 1987: 447). This is caused by the breath qi, which "animates the whole universe from stone to Heaven" and "makes it impossible to imagine a clear separation between spirit and matter and, by implication, flesh and soul. Understandably, a form of animism and its corollary, panpsychism, 
are taken granted by the Chinese" (Tu 1987: 448). Human souls, of which there are two, hun and po, differ from the great gods of the pantheon only in their relative strength (Schipper 1993: 36).

Also the life force ling can be interpreted as the soul ( $\mathrm{Tu}$ 1987: 448). Either way, firstly it means that the human soul does not differ from the souls of other beings and, secondly, that in China there is no egalitarian cosmology to be found as that in the Amazonian described by Viveiros de Castro, but one with value judgments.

If beings are set in a hierarchy, then their respective perspectives are not equal either. Thus in Zhuangzi, although the dependency of things on the perspective is demonstrated, there is one proper perspective, which is the heavenly view of the world (Ivanhoe 1993: 652). Yet, in Amazonia the perspectives are not always equal. For example, Londoño Sulkin writes that this applies to the Muinane people, and true perspective and morality are also linked to each other (Londoño Sulkin 2005: 16).

Value judgments form a connecting link between cosmology and religion. They connect ethics and morality with cosmology and, most importantly, cause some beings to be considered purer than others. But as according to Chinese cosmology everything is in constant change, the boundaries between the profane and transcendent can be crossed. All the matter cleanses with time, so that old things and beings such as trees or turtles are considered holy. Thus, "each person can [---] radiate energy, that is, become transcendent" (Schipper 1993: 41).

In the Journey to the West one can also find a turtle who had, due to his old age, developed further from being an ordinary turtle. He wanted to become human and explained his state to Triptaka as follows:

I have been perfecting myself here for about one thousand years. This is a pretty long span, and I have already been fortunate enough to learn human speech; but I still remain a turtle. I should indeed be very much obliged if you would ask the Buddha how long it will be before I achieve human form. (Waley 1958 [1942]: 277)

It was mentioned before that with time beings become transcendent, yet here the turtle, who already had become a spiritual being, wished to become human. This is because in Chinese cosmology "human beings have the finest of vital forces in the cosmos" (Tu 1987: 448). Thus from all potential beings it is best to be human, which means that being human is automatically being moral.

Surprisingly - considering the egalitarian cosmology of Viveiros de Castro's perspectivism - it is exactly here that one can find important parallels to Amazonian perspectivism. The aforementioned Muinane see perspective, 
bodily substances and morality as intrinsically connected, which adds a religious dimension to perspectivism. Londoño Sulkin writes that "in the narratives I heard, Real People are intrinsically moral because the substances that constitute their bodies and subjectivities are moral; they are so because they originated in the very bodies of the creator and other cool mythical beings, in those felicitous circumstances in which they succeed in creating things truly human" (Londoño Sulkin 2005: 12).

Animals constitute "failures in moral sociality" (ibid.: 13). This is dangerous for humans because animals try to destruct or sabotage the true human perspective and impose their own immoral views on them (ibid.: 15), a situation exactly as in the Journey to the West, in which three animals pretend to be Daoist immortals and persuade the king to oppress the Buddhists.

As Amazonian perspectivism turned out to be useful in interpreting Chinese sources, so can Chinese cosmology help to explain perspectivism.

Due to the important role of transformations in perspectivism one must ask what it is that is being transformed. Perspective alone is not enough, because, as Viveiros de Castro has said, it is not independent but comes from the body. Something must be transformed in order to transform the perspective. I believe that the possibility of transformation is linked to the fact that the body is constructed, because such a processual body indicates that the body is not a biological entity. Transformation is therefore a special case of the construction of the body or its disturbance by an external influence.

This is why I would like to propose a new notion of relations. Perspective is derived from relations or bonds between the subject and its objects. These relations and the perspective are connected because in every relationship it is important to be human and not to establish inter-human relations with nonhumans. In case some of the bonds are destroyed, there is a danger of losing humanity. This can be caused by a supernatural encounter. The network of relations determines what a person is. As the relations change in time, the person's identity also changes; for example, a son becomes a father. The dependency of personhood on relations and its instability were also mentioned by Taylor (1996), and it would fit Turner's notion of bodies and perspectives as sequences of multiple transformations, and would thus remove the contradiction between his and Viveiros de Castro's ideas. The body is the centre of relationships, meaning that the bonds in question are relations between bodies. That may be the reason why the body is important as it is, and much attention is being given to its external signs and markings.

Humans are seen as consisting of relations also in traditional Chinese cosmology, in which a person is not an isolated individuality, but a centre 
of relationships ( $\mathrm{Tu}$ 1987: 448). That is why it may be legitimate to add relations into the model of perspectivism, for as it was previously shown, perspectivism occurs also in the Chinese thought.

The notion of relations could also connect cosmology and society, and would explain why morality and being human are connected. As of the many classical Chinese schools of thought, relations are most prominent in Confucianism, I would like to examine some of its notions more closely. Because Confucianism concentrates mainly on society, one might think that it does not directly concern the current topic. This is, however, not the case because society is part of cosmos, and also because Confucius like Zhuangzi operated with terms that were part of the common cultural background.

Confucius differentiates between true humans and those who are human merely biologically, calling them gentlemen (junzi 君子) and commoners (lit. 'small people' - xiaoren 小人), respectively (Mäll 2009: 24). Perhaps the most important idea in Confucianism is the humanness (ren 仁). Ren manifests in one's relations to other people and is closely linked with ritual ( $l i$ 禮) (Shun 2002). Ergo, being human means behaving in a specific way and having specific relationships. So what I have claimed about perspectivism is already formulated in Confucianism: a true human (junzi) is constructed in a constant process, which requires that one behaves toward others as a human (ren), acts in a specific way $(l i)$, and is through relations or bonds connected to other people, living and dead alike. The Confucian notion of culture (wen 文) may also be added to this list. For Confucius culture connected the present and the past. As behaviour is part of the construction of a human being, it becomes comprehensible why morality is related to being a human.

Returning to Zhuangzi, one can see that these Confucian social ideals, especially ritual behaviour, were vehemently criticised. It is possible to interpret this critique via perspectivism with relations or bonds, as for Zhuangzi it was not the human perspective but the heavenly one that was moral, and his goal was to abolish social bonds. If what a person is depends on relationships or the sum of perspectives, that is, how one sees others and they see him, then a person remains pluralistic. If one abolishes the bonds, also the plurality of perspectives disappears, resulting in the kind of freedom that Zhuangzi propagated. In such a case the first perspective can always remain the "self" or also beyond the "self", thus enabling one to appear to others as one wishes, and at the same time one would see all other things as "they really are". Abolishing the bonds would be exactly the kind of situation as described in Zhuangzi 7.1. 


\section{IN CONCLUSION}

Amazonian perspectivism is a South-American indigenous cosmological notion, according to which every being, independent of its species, sees itself and its species as human. The term was introduced by Eduardo Viveiros de Castro (1998) and has also been successfully applied to other cultural areas, such as North Asia (Pedersen 2001). In the current article I have argued that perspectivism also occurred in pre-modern East Asia. As examples I have used two influential texts from different eras in Chinese history, Zhuangzi (4th-3rd century BCE) and Journey to the West (16th century CE).

As a result, the following could be concluded:

1. Perspectivism helps to understand and interpret classical Chinese texts. The connecting link between East Asia and South America that enables to compare their cosmologies is shamanism.

2. Zhuangzi's philosophy cannot be separated from its cosmological presuppositions.

3. The Chinese concept of relations can be applied to perspectivism. Relations construct the being, and by changing the relations, the being changes as well.

4. In Chinese perspectivism, all perspectives are not equal. The right perspective and morality are intrinsically connected.

\section{NOTES}

1 The notion of animism differs from the classical understanding and is mainly influenced by P. Descola. As there is not much of his work to be found in English, I would like to cite E. Viveiros de Castro (2012) instead. Descola distinguishes between three modes of "objectifying nature": (1) Totemism, in which the differences between natural species are used as a model for social distinctions, i.e., in which the relationship between nature and culture is metaphorical in character and marked by discontinuity (both within and between series); (2) Animism, in which the "elementary categories structuring social life" organise the relations between humans and natural species, thus defining a social continuity between nature and culture, founded on the attribution of human dispositions and social characteristics to "natural beings"; (3) Naturalism, typical of Western cosmologies, which supposes an ontological duality between nature, the domain of necessity, and culture, the domain of spontaneity - areas separated by metonymic discontinuity. 
2 In this article I have used the following translations: for Zhuangzi Richard Wilhelm's German translation (1981 [1912]), James Ware's (1963) and Burton Watson's (1968) English translations, as well as consulted the Chinese text from the two-language text of the Chinese Text Project together with an English translation by James Legge (1891). For the Journey to the West I used the abridged translation by Arthur Waley, titled "Monkey: A Folk Novel of China" (1958 [1942]), and an abridged version of the scholarly translation by Anthony C. Yu (2008). The ethnographic data about South America and North Asia used in this article are derived solely from secondary sources.

\section{REFERENCES}

Asad, Talal 1997. Remarks on the Anthropology of the Body. In: Sarah Coakley (ed.) Religion and the Body. Cambridge: Cambridge University Press, pp. 42-52.

Broz, Ludek 2007. Pastoral Perspectivism: A View from Altai. Inner Asia, Vol. 9, No. 2, pp. 291-310. http://dx.doi.org/10.1163/146481707793646566.

Connolly, Tim 2011. Perspectivism as a Way of Knowing in the Zhuangzi. Dao, Vol. 10, No. 4, pp. 487-505. http://dx.doi.org/10.1007/s11712-011-9246-x.

Costa, Luiz \& Fausto, Carlos 2010. The Return of the Animists: Recent Studies of Amazonian Ontologies. Religion and Society: Advances in Research, Vol. 1, No. 1, pp. 89-109. http://dx.doi.org/10.3167/arrs.2010.010107.

DeBernardi, Jean 1995. On Trance and Temptation: Images of the Body in Malaysian Chinese Popular Religion. In: Jane Marie Law (ed.) Religious Reflections on the Human Body. Bloomington \& Indianapolis: Indiana University Press, pp. 151-165.

Giskin, Howard 2004. Dreaming the Seven-Colored Flower. Asian Folklore Studies, Vol. 63, No. 1, pp. 79-94.

Halbmayer, Ernst 2012. Debating Animism, Perspectivism and the Construction of Ontologies. Indiana, Vol. 29, pp. 9-23. Available at http://www.iai.spk-berlin. de/fileadmin/dokumentenbibliothek/Indiana/Indiana_29/IND_29_2012_009023_Halbmayer.pdf, last accessed on September 30, 2014.

Ivanhoe, Philip J. 1993. Zhuangzi on Skepticism, Skill, and the Ineffable Dao. Journal of the American Academy of Religion, Vol. 61, No. 4, pp. 639-654. doi:10.1093/ jaarel/LXI.4.639.

Kim, Chŏng-Ho 2003. Korean Shamanism: The Cultural Paradox. Aldershot, UK: Ashgate.

Kristensen, Benedikte M. 2007. The Human Perspective. Inner Asia, Vol. 9, No. 2, pp. 275-289. http://dx.doi.org/10.1163/146481707793646467.

Latour, Bruno 2009. Perspectivism: 'Type' or ‘Bomb’? Anthropology Today, Vol. 25, No. 2 , pp. 1-2. http://dx.doi.org/10.1111/j.1467-8322.2009.00652.x.

Legge, James (trans.) 1891. Zhuangzi. Chinese Text Project. Source: The Writings of Chuang Tzu. Available at http://ctext.org/zhuangzi, last accessed on October 1, 2014 . 
Lévi-Strauss, Claude 2010. Rass ja ajalugu. Rass ja kultuur. [Race and History. Race and Culture.] Transl. by Indrek Koff. Tallinn: Varrak.

Lima, Tânia Stolze 1999. The Two and its Many: Reflections on Perspectivism in a Tupi Cosmology. Ethnos: Journal of Anthropology, Vol. 64, No. 1, pp. 107-131. http:// dx.doi.org/10.1080/00141844.1999.9981592.

Londoño Sulkin, Carlos D. 2005. Inhuman Beings: Morality and Perspectivism among Muinane People (Colombian Amazon). Ethnos: Journal of Anthropology, Vol. 70, No. 1, pp. 7-30. http://dx.doi.org/10.1080/00141840500048474.

Mäll, Linnart 2009. Konfutsiuse suurus ja ulatus. [Greatness and Scope of Confucius.] In: Märt Läänemets (ed.) Hiina Mõttevaramu 1: Konfutsius. Tartu: Lux Orientis, pp. 13-37.

Mrozik, Susanne 2007. Virtuous Bodies: The Physical Dimensions of Morality in Buddhist Ethics. New York: Oxford University Press.

Pedersen, Morten A. 2001. Totemism, Animism and North Asian Indigenous Ontologies. Journal of the Royal Anthropological Institute, Vol. 7, No. 3, pp. 411-427. http:// dx.doi.org/10.1111/1467-9655.00070.

Rasmussen, Susan 2011. Encountering Being, Identity, and Otherness: Reconsidering Guimarães's “Amerindian Anthropology and Cultural Psychology" and Amerindian Perspectivism, with Insights from Anthropology of Religion, African Humanities, and Collaborative Ethnography. Culture \& Psychology, Vol. 17, No. 2, pp. 159-176. doi:10.1177/1354067X11400953.

Rival, Laura 2005. The Attachment of the Soul to the Body among the Huaorani of Amazonian Ecuador. Ethnos: Journal of Anthropology, Vol. 70, No. 3, pp. 285-310. http://dx.doi.org/10.1080/00141840500294300.

Robinet, Isabelle 1997. Taoism: Growth of a Religion. Stanford: Stanford University Press.

Santos-Granero, Fernando 2009. Introduction: Amerindian Constructional Views of the World. In: Fernardo Santos-Granero (ed.) The Occult Life of Things: Native Amazonian Theories of Materiality and Personhood. Tucson: The University of Arizona Press, pp. 1-29. Available at http://www.stri.si.edu/sites/publications/ PDFs/STRI-W_2009_S-G_Amerindian_Constructional_Views_World.pdf, last accessed on September 30, 2014.

Schipper, Kristofer 1993. The Taoist Body. Berkeley \& Los Angeles: University of California Press.

Shun, Kwong-Loi 2002. Rén仁and Li 禮in the Analects. In: Bryan W. Van Norden (ed.) Confucius and the Analects: New Essays. Cary, NC: Oxford University Press, pp. 53-72.

Silva Guimarães, Danilo 2011. Amerindian Anthropology and Cultural Psychology: Crossing Boundaries and Meeting Otherness' Worlds. Culture \& Psychology, Vol. 17, No. 2, pp. 139-157. http://dx.doi.org/10.1177/1354067X11398309.

Sturgeon, Donald (forthcoming). Zhuangzi, Perspectives and Greater Knowledge. Philosophy East and West, Vol. 65, No. 3. Available at http://dsturgeon.net/papers/ Zhuangzi_perspectives_and_greater_knowledge.pdf, last accessed on October 10, 2014. 
Taylor, Anne Christine 1996. The Soul's Body and its States: An Amazonian Perspective on the Nature of Being Human. The Journal of the Royal Anthropological Institute, Vol. 2, No. 2, pp. 201-215. http://dx.doi.org/10.2307/3034092.

Tu, Wei-Ming 1987. Soul: Chinese Concepts. In: Mircea Eliade (ed. in chief) The Encyclopedia of Religion. Volume 13 [Sain-Spek]. New York: Macmillan \& London: Collier Macmillan, pp. 447-450. Available at http://people.uwec.edu/beachea/ chinsoul.html, last accessed on September 30, 2014.

Turner, Terry S. 2009. The Crisis of Late Structuralism. Perspectivism and Animism: Rethinking Culture, Nature, Spirit, and Bodiliness. Tipití: Journal of the Society for the Anthropology of Lowland South America, Vol. 7, No. 1. Available at http:// digitalcommons.trinity.edu/tipiti/vol7/iss1/1, last accessed on September 15, 2014.

Vilaça, Aparecida 2005. Chronically Unstable Bodies: Reflections on Amazonian Corporalities. The Journal of the Royal Anthropological Institute, Vol. 11, No. 3, pp. 445-464. http://dx.doi.org/10.1111/j.1467-9655.2005.00245.x.

Vimalakīrtinirdeśa Sūtra 2006 = Vimalakīrtinirdeśa: $A$ Sanskrit Edition Based upon the Manuscript Newly Found at the Potala Palace. Study Group on Buddhist Sanskrit Literature, the Institute for Comprehensive Studies of Buddhism, Taisho University. Tokyo: Taisho University Press.

Viveiros de Castro, Eduardo 1998. Cosmological Deixis and Amerindian Perspectivism. The Journal of the Royal Anthropological Institute, Vol. 4, No. 3, pp. 469-488. doi: $10.2307 / 3034157$.

Viveiros de Castro, Eduardo 2010. In Some Sense. Interdisciplinary Science Reviews, Vol. 35, No. 3, pp. 318-333. http://dx.doi.org/10.1179/030801810X12772143410241.

Viveiros de Castro, Eduardo 2012. Cosmological Perspectivism in Amazonia and Elsewhere. Four lectures given in the Department of Social Anthropology, Cambridge University, February-March 1998. HAU: Masterclass Series, Vol. 1. Available at http://www.haujournal.org/index.php/masterclass/issue/view/ Masterclass\%20Volume\%201, last accessed on September 30, 2014.

Waley, Arthur (trans.) 1958 [1942]. Monkey: A Folk Novel of China. By Wu Cheng-en. New York: Grove Press.

Ware, James R. (trans.) 1963. The Sayings of Chuang Chou. By Zhuangzi. New York: New American Library.

Watson, Burton (trans.) 1964. Chuang Tzu: Basic Writings. By Zhuangzi. New York: Columbia University Press.

Wilhelm, Richard (trans.) 1986 [1912]. Dschuang Dsi. Das Wahre Buch vom südlichen Blütenland. By Zhuangzi. Köln: Diederichs.

Willerslev, Rane \& Ulturgasheva, Olga 2012. Revisiting the Animism versus Totemism Debate: Fabricating Persons among the Eveny and Chukchi of North-Eastern Siberia. In: Marc Brightman \& Vanessa Elisa Grotti \& Olga Ulturgasheva (eds.) Animism in Rainforest and Tundra: Personhood, Animals, Plants and Things in Contemporary Amazonia and Siberia. New York and Oxford: Berghahn Books, pp. 48-68. 
Erki Lind

Yu, Anthony C. (trans.) 2008. The Monkey and the Monk: An Abridgment of the Journey to the West. By Wu Cheng-en. Chicago, IL: University of Chicago Press. 